\title{
Transitioning to sustainable use of biofuel in Australia
}

\author{
Nugroho Adi Sasongko ${ }^{1,2,3,}{ }^{*}$, Charlotte Thorns ${ }^{1}$, Irina Sankoff ${ }^{1}$, Shu Teng Chew ${ }^{1}$, and Sangita Bista ${ }^{1}$ \\ ${ }^{1}$ School of Engineering and Information Technology, Murdoch University, Perth, Australia \\ ${ }^{2}$ Graduate School of Life and Environmental Sciences, University of Tsukuba, Tsukuba, Japan \\ 3 The Agency of Assessment and Application of Technology (BPPT), Tangerang Selatan, Indonesia
}

Received: 17 January 2017 / Received in final form: 7 July 2017 / Accepted: 27 July 2017

\begin{abstract}
Biofuel is identified as one of the key renewable energy sources for sustainable development, and can potentially replace fossil-based fuels. Anticipating the competition between food and energy security, the Australian Government is intensively exploring other biofuel resources. There have been numerous research projects in Australia using the second and third generation model based on different feedstocks including lignocellulosic and microalgae. Such projects have been successfully demonstrated but are yet to be commercially viable. Moreover, transition pathways to realize the potential benefits of these value chains are not well understood. This preliminary study tried to provide an alternative framework and proposes future longterm transport biofuel pathways in Australia which can be seen as a solution for a post-carbon society. The study is targeted to outline the milestone of the Australian biofuel industry and its roadmap into the future. An investigation has been carried out on biofuel status and barrier, technology development, market and the chronology of biofuel related policies in Australia to understand the current situation and possibilities to develop further strategies, while also providing an insight into the consequences of producing biofuel for transportation. Several methods have been proposed to introduce the transition into a post-carbon society. Seven scenarios were divided, covering the roadmap of first, second and third generation of biofuel, alternative transportation modes such as electric vehicles (EVs) and fuel cell vehicles (FCVs) and the elimination of the fossil fuel running vehicles within a time frame of 20 years. The utilization of biofuel can be seen as a short to medium mode for transition into a green transportation society. Our investigation also showed that microalgae gave a better ecological footprint which offers the strongest potential for future Australian biofuel industry and aviation. Meanwhile, $\mathrm{EVs}$ and FCVs also share the portion for long-term transportation modes scenario.
\end{abstract}

\section{Introduction}

Climate change is one of the biggest challenges of this century. Rapid accumulation of carbon emissions in our atmosphere will eventually lead to irreversible impacts of climate change to various systems of Earth [1]. The science has always been clear to show that the danger of climate change to humanity is real and actions are needed to tackle this situation [2]. It is also a fact that carbon dioxide is one of the main sources that is causing pollution and climate change. Meanwhile, the world energy crisis and increased greenhouse gas emissions have driven the exploration for alternative and environmentally friendly sources. Currently, many other alternative sources have been used to replace fossil fuel in order to reduce carbon

\footnotetext{
^ Paper presented at: World Renewable Energy Congress XVI, 5-9 February 2017, Murdoch University, Perth, Australia.

* e-mail: nugroho.adi.sasongko@gmail.com
}

emission's effect on climate change. Biofuel, being any fuel that is produced from organic matter resulting from agriculture or forestry, is a type of renewable energy that, may be a solution to reducing the world's reliance on fossil fuels [3]. Biofuel can be categorized into first, second and third generation as shown in Figure 1.

The blend concentration of biofuel in diesel and other fuels differs between countries, $2 \%, 5 \%, 20 \%$ and $100 \%$ concentrations of biofuel are amongst the most common, marketed in the form of B2, B5, B20 and B100 blends respectively. On the other hand, ethanol is normally blended with petrol in concentrations of $10 \%$ and marketed as E10 [4]. Biofuel is a good source of energy that can assist in reducing waste and carbon emissions. Fossil fuel accounts for $80.3 \%$ of the world's primary energy consumption, of which $57.7 \%$ is used in the transportation sector [4]. In Australia, this is the second largest energy consuming area and continues to grow steadily by $1 \%$ each year. Oil import reliance has increased, with $85 \%$ of refinery feedstock and $45 \%$ of 


\section{$\begin{array}{llll}\text { Feedstocks } & \text { Parts used } & \text { Conversion processes } & \text { Biofuel products }\end{array}$}

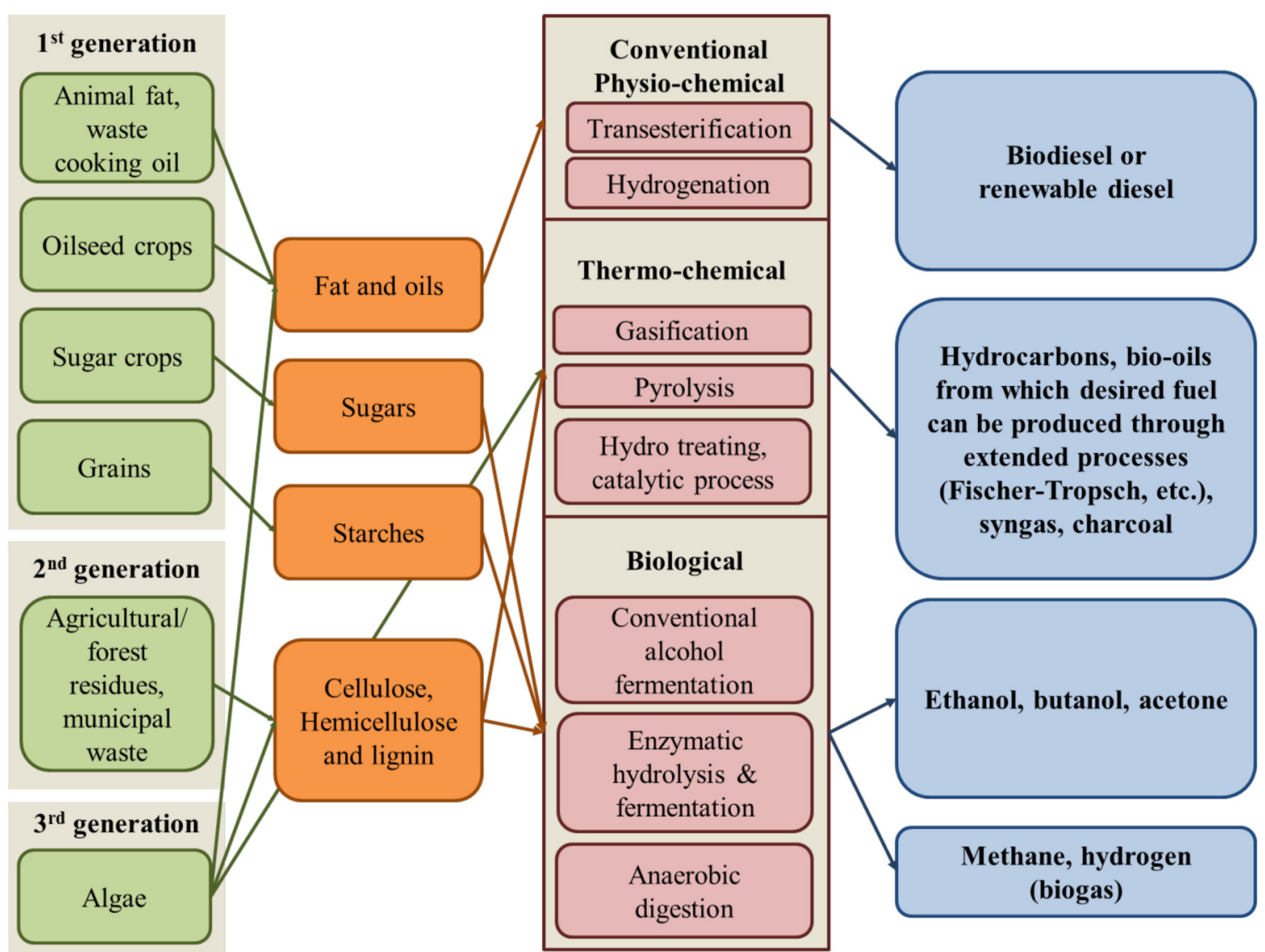

Fig. 1. Biofuel generation based on the feedstock, processes and products.

refined production consumption is now met from imports [5]. Figure 2 shows the fuel projection in Australia from 2015 to 2025.

According to a 2014 study by the National Transport Commission the average annual carbon dioxide emissions ratings of new passenger vehicles and light commercial vehicles was $192 \mathrm{~g}$ per kilometer travelled, this is a $3.4 \%$ reduction from 2012 and is the third largest annual reduction since records started in 2002. Australia's national average carbon emissions from new passenger vehicles are comparatively high. Some factors contributing to this is the consumer preference for heavier vehicles and a lower proportion of diesel powered engines. Research on biofuels suggests that average carbon emissions from cars can be lowered through the use of ethanol and biodiesel as transport fuels [6].

Additionally, findings have been showing encouraging results that the displacement of fossil fuel can result in average net reduction in cellulosic ethanol. Commercial biofuel production in Australia has increased from almost zero in the year 2000 to approximately 330 million litres in 2016 comprised of 250 and 50 million litres of ethanol and biodiesel, respectively [6]. In fact, Australia is currently one of the world's 20 largest biofuel production countries [7]. As a result, the production is projected to increase for at least the next 30 years. Therefore, wide spread use and biofuel production could be key to greenhouse gas (GHG) emission mitigation in Australia. Hence, we have proposed this study to be one of the measures taken to introduce transition to a post-carbon society.

\section{Methodology}

\subsection{Current Australian policies on biofuel production and use}

Research on Australian policies such as the Biofuels Act 2007 (NSW), Biofuels Amendment Bill 2012 (NSW) and Liquid Fuel Supply (Biofuel Mandate) Amendment Bill 2017 (Qld), has been implemented in the transitioning project to assess which policies have been implemented in Australia and if there is a need for improvement in the current and future policies considering commercialization of biofuel. The findings on the history of biofuel policies in Australia have been constructed to outline the transition process timeline.

\subsection{Ecological footprint model}

An ecological footprint model has been investigated in this transitioning project to assess which biofuel crop source is the most effective to produce. Ecological footprint accounting measures the demand and supply of nature. On the demand side, the ecological footprint measures the ecological assets that a given population requires to 


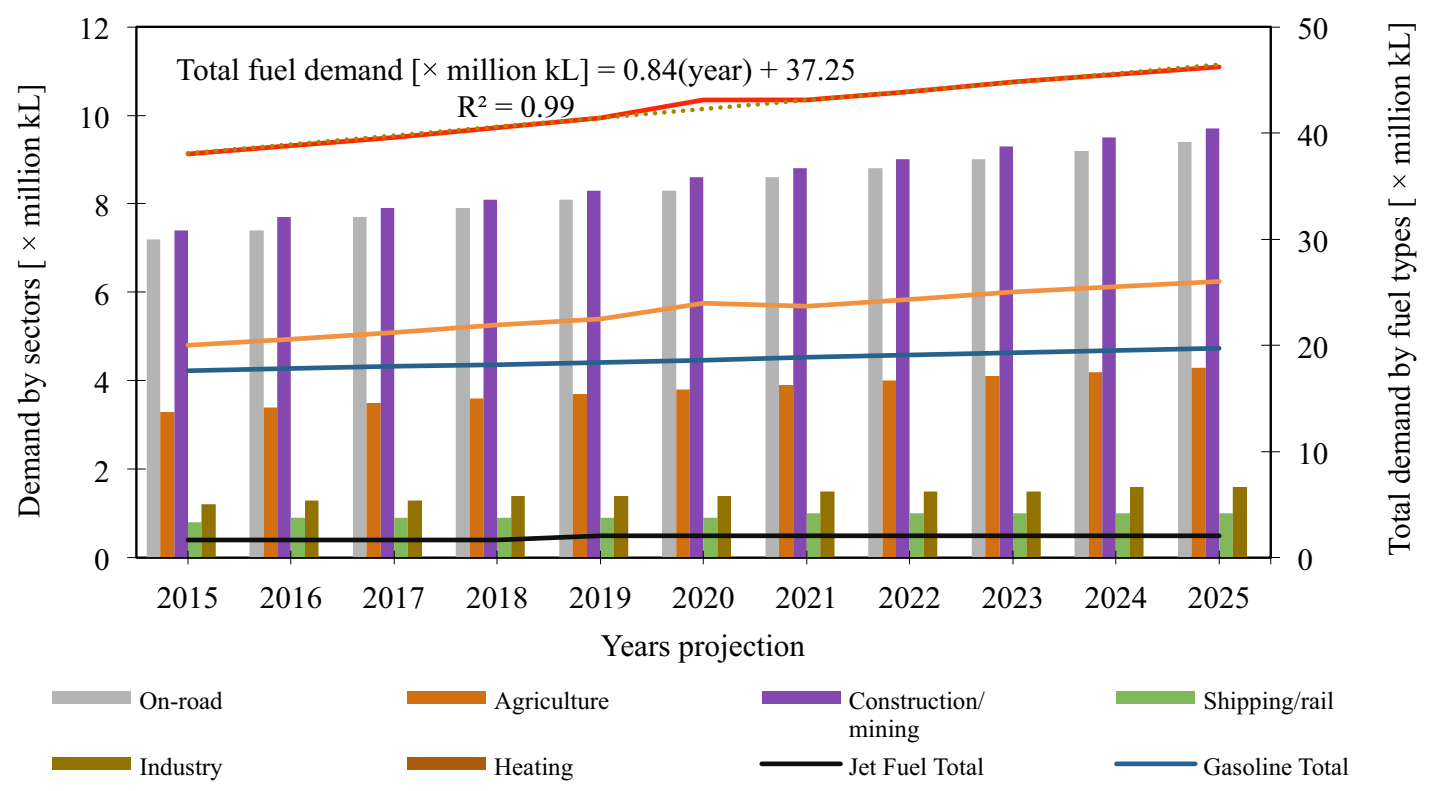

Fig. 2. Australian fuel use projections, 2015 up to $2025[5,6]$.

produce the natural resources it consumes and to absorb its waste, especially carbon emissions. On the supply side, a city, state or nation's biocapacity represents the productivity of its ecological assets [8]. In this study, the ecological footprint model is based on the selected crops that might be possible to grow in Australia, such as sun flower, rapeseed, palm oil and microalgae. The model is based on the number of registered personal vehicles in 2015 , the average emission intensity for light commercial vehicles in 2014 and the average rate of fuel consumption for $100 \mathrm{~km}$ with references and calculations $[9,10]$. The model is also based on B20 and B100 blends to compare which blend has the lowest ecological footprint. The calculations used in this model were based on L/vehicle/year, kL/ha/year, global hectares per capita and percentages $(\%)$. The water footprint was also calculated for each biofuel crop to assess the water usage requirements [11,12]. Units for water footprint calculations were based on $\mathrm{m}^{3} / \mathrm{ha} /$ year.

\subsection{Limitations of commercial usage of biofuel}

Research on the limitations of the commercial usage of biofuel has been carried out in this study to address the future challenges that transitioning into a society relying on biofuels will face. Previous studies that addressed the current and future limitations of biofuel were analysed and discussed in this project.

\subsection{Transitioning timeline}

A plan for the biofuel transitioning project has been implemented based on seven proposed scenarios that are planned to occur within and after the 20 year proposed time frame. The scenarios were chosen to outline different developments in generations of biofuel sources (1st, 2nd and 3rd generation) and alternative modes of sources (electric vehicles and fuel cell vehicles).

\section{Results and discussion}

\subsection{Political climate and policies surrounding biofuels today}

As outlined in the biofuels taskforce report to the Prime Minister 2005 [13], there is little to no consumer demand for biofuels. As a result of this, there is no drive for companies to promote ethanol or biodiesel blends or for new producers to invest. Unfortunately to date, this has not changed much particularly since the abolition of the biofuel excise free status (Ethanol Production Grant and Cleaner Fuels Grant Scheme), where the duty rates for ethanol will slowly increase annually until the final rate is reached in 2020 and biodiesel will increase until the final rate is reached in 2030. As a result consumers are still very unconvinced and sceptic on ethanol or biodiesel blends.

- as shown in Figure 3, there have been attempts by state governments to implement biofuel blend mandates, which is described as the minimum quantity of ethanol or biodiesel (by volume, usually denoted as a percentage) that service stations must sell: the Western Australian Biofuels Taskforce in 2006 suggested that the state government introduce an ethanol mandate however there has been no response [14]; 


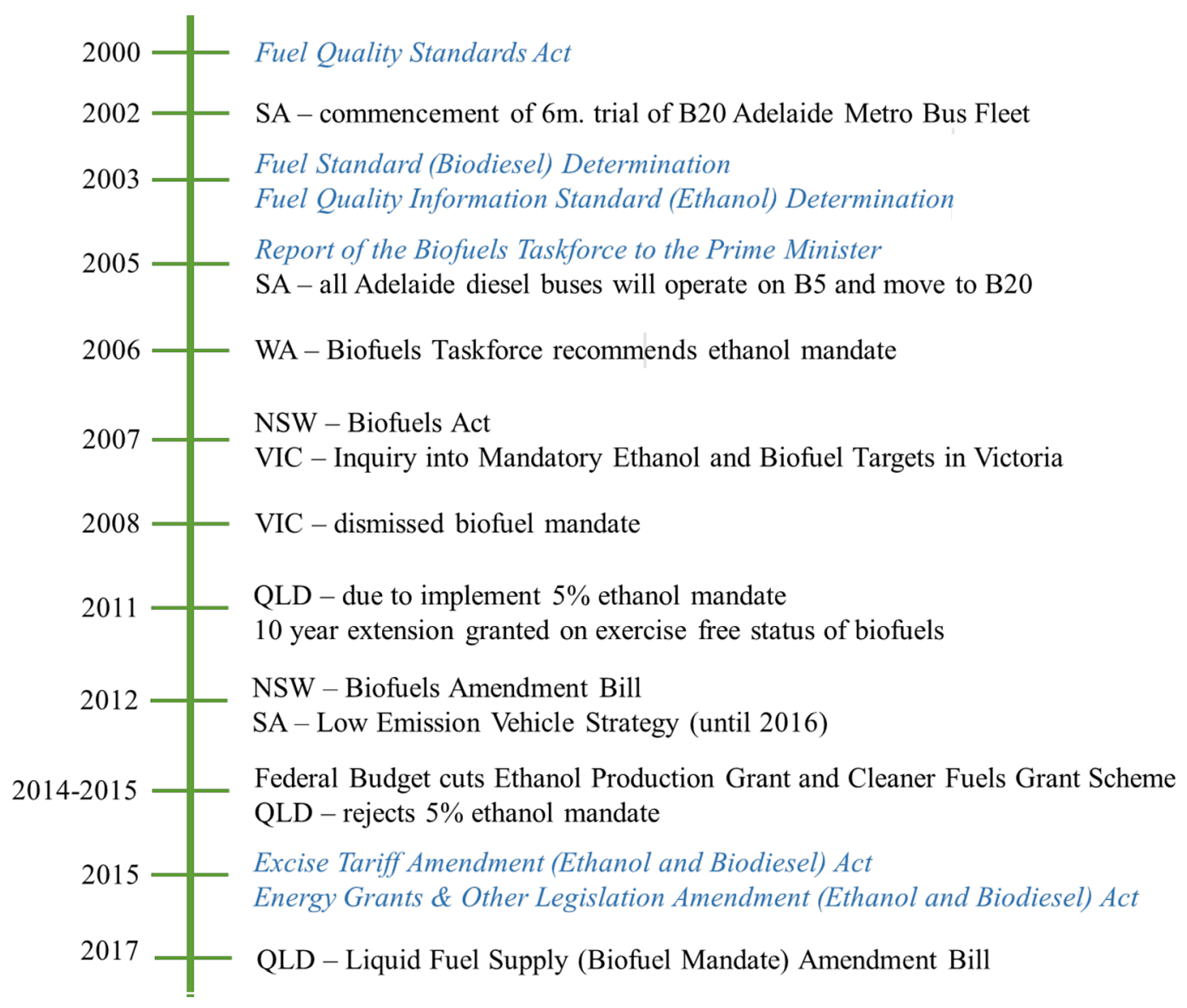

Fig. 3. Timeline of Australian policies and commissioned reports on biofuels.

- New South Wales introduced the Biofuels Act 2007 No. 23 which required $6 \%$ of the total (volume) petrol sold in the state to be ethanol. It eventually aimed to replace all regular unleaded petrol (RULP) with a $10 \%$ ethanol blend (E10). None of the objectives were reached, primarily due to amendments [15]. More recently, we have seen a resurgence of this mandate with the Biofuels Amendment Act 2016 (6\% of RULP sold must be E10 and $5 \%$ of diesel sold must be B5 or B20) however it is unclear when it will take effect;

- The Economic Development \& Infrastructure Committee (EDIC) received terms of reference for the Inquiry into Mandatory Ethanol and Biofuel Targets in Victoria. By 2008 EDIC dismissed a biofuels mandate [16,17];

- despite an initial unsuccessful attempt at a biofuel mandate in 2011 due to uncertainties regarding the excise free status of biofuels, the Queensland government successfully passed the Liquid Fuel Supply (Biofuel Mandate) Amendment Bill 2015 (Qld) [18,19]. The bill will take effect in January 2017 (and has been amended since) where $3 \%$ of total (volume) of RULP sold must be ethanol, with it increasing to $4 \%$ after 8 months. Additionally, $0.5 \%$ of total (volume) of diesel sold must be biodiesel;

- other states like South Australia are encouraging developments and commercialization of biofuels (Low Emissions Vehicle Strategy 2012-2016 aimed to increase the amount of biofuel sales and the Adelaide Metro bus fleet operates on B5/B20 biodiesel blends) but are not putting a mandate on this [20].

The aforementioned tax cuts have made it more difficult for biofuels to establish market competitiveness. At the same time, the mandates that have been passed have been receiving criticisms from agencies such as the Australian Competition \& Consumer Commission in their Report on the Australian petroleum market (December quarter 2015) as well as the Australian Automobile Association which indicate their distaste in the lack of consumer choice such policies bring about. By reducing consumer choice, people are either forced to spend more on ethanol/biodiesel blends or are having to travel further to other retailers to purchase fuel. This in turn affects the competitiveness between service retailers. However, following the timeline of Australian policies, developing a balanced policy framework is necessary to harmonize the state and federal energy agencies, greater transparency across agency activities and information and clear linkages between the energy sector and climate change policy.

\subsection{Ecological footprint of biofuels in Australia}

Referred to Australian Bureau of Statistics in 2015, there was 18.40 million registered vehicles included $45 \%$ running on the diesel engine (6.22 million vehicles) [9]. In 2015, the 
Table 1. Research findings on ecological footprint from selected biofuel crops in Australia.

\begin{tabular}{|c|c|c|c|c|c|}
\hline Items & Unit & Sun flower & Rapeseed & Palm oil & Microalgae \\
\hline Bio-oil production & $\mathrm{kL} / \mathrm{ha} /$ year & 0.44 & 1.20 & 3.69 & 27.23 \\
\hline \multicolumn{6}{|l|}{ Land required } \\
\hline B100 & ha & 9116120 & 5864500 & 2262110 & 337299 \\
\hline B20 & ha & 1823224 & 1172900 & 452422 & 67459 \\
\hline \multicolumn{6}{|l|}{ Ecological footprint } \\
\hline B100 & ha/cap & 0.38 & 0.14 & 0.05 & 0.04 \\
\hline $\mathrm{B} 20$ & $\mathrm{ha} / \mathrm{cap}$ & 0.08 & 0.03 & 0.02 & 0.01 \\
\hline Australian ecological footprint (EF) [8] & Global ha/cap & 6.25 & 6.25 & 6.25 & 6.25 \\
\hline \multicolumn{6}{|l|}{$\%$ of Australian } \\
\hline EF B100 & $\%$ & 6.13 & 2.24 & 0.84 & 0.62 \\
\hline EF B20 & $\%$ & 1.23 & 0.48 & 0.32 & 0.12 \\
\hline Water footprint & Million $\mathrm{m}^{3} / \mathrm{ha} /$ year & 10939 & 8931 & 7704 & 1113 \\
\hline $\mathrm{CO}_{2}$ footprint including average ILUC & $\mathrm{gCO}_{2} / \mathrm{MJ}$ & \multicolumn{4}{|c|}{ Biofuel emission 31-150 [22] } \\
\hline
\end{tabular}

Australian national average emission intensity for new passenger and light commercial vehicles was $184 \mathrm{~g} \mathrm{CO}_{2} /$ $\mathrm{km}$. By taking average rate $10.70 \mathrm{~L}$ of fuel consumption for each $100 \mathrm{~km}$ driving range in Australia, we found that $1476.60 \mathrm{~L} /$ vehicle/year is a potential amount that could be replaced by biodiesel. Since the current available internal combustion engine technology is only capable to use up to $20 \%$ of biodiesel by fuel mixing, therefore by total 1652936 t B100/year should be produced to fulfil the fuel demand in Australia. Based on several references, current microalgae biomass production growth rate is ranged from 10 to $30 \mathrm{~g} / \mathrm{m}^{2} /$ day for open pond cultivation [20,21]. Taken as assumption $25 \mathrm{~g} / \mathrm{m}^{2}$ /day biomass productivity with $30 \%$ of lipid contain, $27.3 \mathrm{~kL}$ of biodiesel is estimated to be able to be produced in each hectare cultivation pond annually. By assuming all the environmental conditions are constant, the total land required for B20 and B100 production are 67460 ha and 337300 ha, respectively. The size of B20 land required is equal to the size of Singapore Island $\left(719.1 \mathrm{~km}^{2}\right)$. Meanwhile, B100 land required is almost 3 times size of the Mundaring state forest in Western Australia. Following the calculation of ecological footprint (0.04 for B100 and 0.01 for B20), the percentage difference compared to Australian Ecological footprint was $0.62 \%$ and $0.12 \%$ for $\mathrm{B} 100$ and B20 production, respectively.

In addition, the total water footprint for microalgae based biofuel life cycle was calculated. Mekonnen and Hoekstra estimated that at least $3000 \mathrm{~m}^{3}$ water $/ \mathrm{t}$ of microalgae based biodiesel from cultivation stage until biodiesel product (cradle to gate) $[11,12]$. In overall, 4.96 billion $\mathrm{m}^{3}$ and 24.79 billion $\mathrm{m}^{3}$ of water are required for $\mathrm{B} 20$ and $\mathrm{B} 100$ production cycle, respectively. By comparing the pros and cons of several biofuel crops production, microalgae are the strongest potential crops for future Australia biofuel industry. Summary of total land, production and footprints (ecological and water) analyses is displayed in Table 1.

\subsection{The limitations and challenges of biofuel utilization}

Producing biofuel for personal vehicles in Australia has large impacts and limitations on food security, the environment, supply and demand and cost. The main deterrents of producing and consuming biofuel are food security and land availability [24]. Setting aside land for biofuel crops creates a demand on the land available for food production. United Nations experts state that biofuel sources such as ethanol can reduce carbon emissions and generate jobs for the lower class population in rural regions [4]. Even though this scenario sounds promising for the future, there are some trade-offs involved in the process of producing crops for biofuel use only. The benefits of biofuel in the future could be eliminated by serious environmental problems, causing the rise in food prices, if the growth of the biofuel industry occurs inordinately. In the case of large-scale biofuel industries, there are likely to be competing markets not just for feedstock and agriculture, but also for the factors of production of water, land and labour [25]. These demands will have a tremendous impact on many industry sectors in Australia.

Future challenges of biofuel in Australia include several issues:

- High cost of biofuel production

Currently, infrastructure, energy and water for biofuel production are high in cost, following low productivity of edible oil (lipid) for biodiesel and sugar production causing a restriction of use and production in many countries [26]. There is however, some ongoing research investigating alternative technologies that diminish the costs of infrastructure and energy demand involved in producing biofuels.

- Fertilizers utilization and water scarcity

There will be more competition in fertilizers demand between crops for food, feed and biofuels. World nitrogenbased fertilizer consumption for biofuel production was 


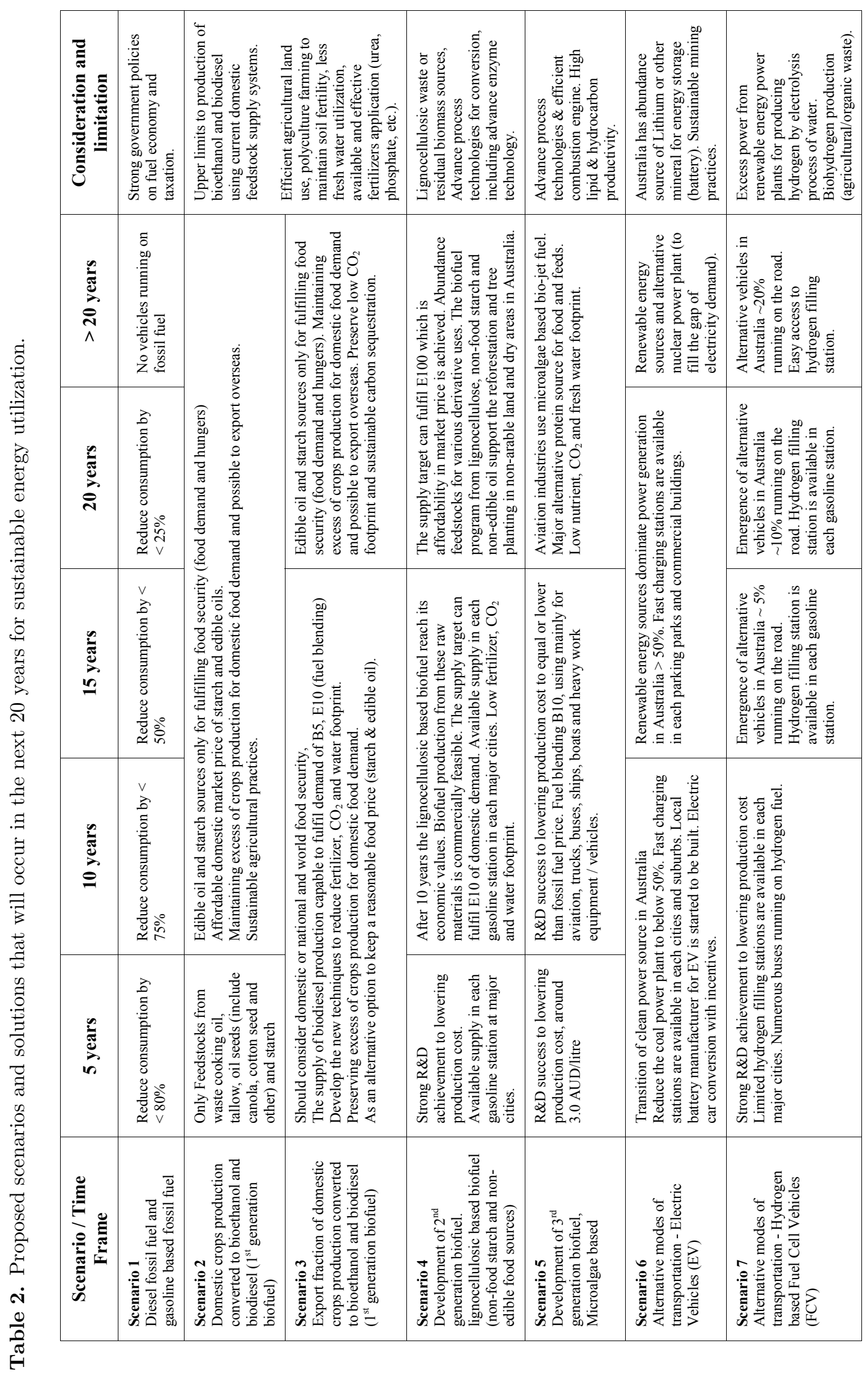


estimated to be 3.4 million tons of nitrogen for the 2013/ 2014 growing period and corresponds roughly to $3.1 \%$ of global nitrogen consumption [27]. With regards to increase the use of water, Australia faces major challenges in ensuring a sustainable water supply with increasing stress between a drying climate and rising demand [18,26]. Australia presently has no specific strategy, rules or regulations relating to biofuels and the regulation of water use [7,13-20,26]. The Australian government identifies the intensification of biofuels crops production has the potential to increase water and fertilizer use, and the need for long term planning of water supply against the increasing competition between usages.

- Negative impact of land use change to biodiversity conservation and environment

Australia currently has no definite policy, rules or regulations relating to biofuel production with regard to protection of biodiversity or environmental sustainability. As with any land use change in Australia, growing feedstock for biofuels or using waste from agricultural crops or timber production must meet legislation and regulations governing land use, water use and environmental impacts in generally. The monoculture farming method for biofuel crops is feared will reduce the biodiversity of the origin land used. Land use change for biofuel production and for other purposes, is a topic of important discussion in United Nations Framework Convention on Climate Change negotiations under the banner of reducing emissions from deforestation and forest degradation (REDD) in developing countries [28]. Australia promotes the use of market-based incentives for REDD, and was one of the first countries to commit funds for REDD capacity building and readiness actions [28].

- GHG emissions

Australia is concerned in the climate change mitigation potential of biofuels. However, Australia recognizes that there are significant gaps in knowledge needing research in order to better understand the potential emission impacts of biofuels, as well as the best way to address these impacts. The Australian biofuel roadmap estimate that by $2020,5 \%$ bio jet fuel share could be possible in Australia and New Zealand, expanding to $40 \%$ by 2050 [28]. Aviation industry is one of main potential biofuel supplies in response to the Australian government's emission reduction fund safeguard mechanism, to keep the emissions within baseline levels from 1 July $2016[2,20,29]$.

- Food security in Australia

One of the main concerns regarding the expansion of the biofuel industries is that potential feedstock production would displace croplands currently used for food crops. The conflicting issues on food security can be diminished by using third generation biofuel sources as it can be an alternative source of protein and carbohydrates [30,31]. Additional co-products of animal feeds and bio-fertilizers can be obtained from defatted microalgae biomass.

\subsection{Proposed scenario and timeframe}

Table 2 shows the proposed scenario and timeframe of sustainable transition of biofuel in Australia. The optimistic design is proposed in regards to accelerating the Australian transition into a post-carbon society. The world energy crisis and increased greenhouse gas emissions have driven the exploration for alternative and environmentally friendly sources. According to recent life cycle analysis, microalgae biofuel is identified as one of the key renewable energy sources for sustainable development, with potential to replace the fossil-based fuels $[21,30,32,33]$.

\section{Conclusions}

The proposed transition time line is important to be recognized by multiple campaigns running at appropriate times for each segment of our transition. A campaign for the transition of post-carbon society is necessary to be conducted in order to raise awareness towards the public about how important the transitioning project is and how transitioning to biofuels will benefit the reduction of carbon emissions. A future education campaign will also be explored and implemented into this project, to educate the public. Further, an appropriate educational campaign should involve political advocacy primarily through lobbying groups such as the Biofuels Association of Australia and National Farmers Federation. A direct appeal to public audiences by creating a public education campaign, such as Queensland's "E10 OK" is a good campaign strategy tactic for ethanol blends as well as other biodiesel blends. The campaign is somewhat unique in that it will involve institutional (government) agencies (which intend to change individual's lifestyle behaviours and consumer choices) as well as an environmental advocacy campaign (which set out to systematically change external conditions).

\section{References}

1. S. Lim, K.T. Lee, Implementation of biofuels in Malaysian transportation sector towards sustainable development: a case study of international cooperation between Malaysia and Japan, Renew. Sustain. Energy Rev. 16, 1790 (2012)

2. The Climate Institute, Climate change science (2016), Available from: http://www.climateinstitute.org.au

3. L.P. Koh, J. Ghazoul, Biofuels, biodiversity, and people: understanding the conflicts and finding opportunities, Bio. Conserv. 141, 2450 (2008)

4. J.C. Escobar et al., Biofuels: environment, technology and food security, Renew. Sustain. Energy Rev. 13, 1275 (2009)

5. Office of the Chief Economist, Australian Energy Update (2016)

6. USDA Foreign Agricultural Service, Australia, Biofuels Annual (2016)

7. A.K. Azad et al., Prospect of biofuels as an alternative transport fuel in Australia, Renew. Sustain. Energy Rev. 43, $331(2015)$ 
8. Global Footprint Network, Ecological Footprint (2017), Available from: http://www.footprintnetwork.org/

9. Australian Bureau of Statistics, Motor vehicle census, Australia (2016)

10. Climate Change Authority, Light vehicle emissions standards for Australia: research report, Canberra (2014) pp. 5103

11. M.M. Mekonnen, A.Y. Hoekstra, The green, blue and grey water footprint of crops and derived crop products, Hydrol. Earth Syst. Sci. 15, 1577 (2011)

12. M.M. Mekonnen, A.Y. Hoekstra, Water footprint benchmarks for crop production: a first global assessment, Ecol. Indicat. 46, 214 (2011)

13. Australian Government Biofuels Taskforce, Report of the Biofuels Taskforce to the Prime Minister (2005)

14. Western Australia Biofuels Taskforce, Interim Report (2007)

15. Parliament of New South Wales, Biofuels Amendment Bill 2012 (2012)

16. Economic Development and Infrastructure Committee, Inquiry into Mandatory Ethanol and Biofuels Targets (2007)

17. ACIL Tasman, Current and potential fuels for transport in Victoria, prepared for the Department of Transport and the Department of Primary Industries Victoria (2008)

18. Department of Energy and Water Supply, Towards a clean energy economy: achieving a biofuel mandate for Queensland (2015)

19. The Alliance Against Ethanol Mandates, Response to the Qld Biofuels Mandate Discussion Paper (2015)

20. A. Doshi, Economic Analyses of Microalgae Biofuels and Policy Implementations in Australia, Ph.D. thesis (Queensland University of Technology, 2017). Available from: https://eprints.qut.edu.au/103532/1/Amar_Doshi_The sis.pdf

21. IEA Bioenergy, State of Technology Review - Algae Bioenergy (2017)
22. European Parliament, The Impact of Biofuels on Transport and the Environment, and Their Connection with Agricultural Development In Europe (2015)

23. S. de Jong et al., Life-cycle analysis of greenhouse gas emissions from renewable jet fuel production, Biotechnol Biofuels 10, 64 (2017)

24. University of Minnesota, Alternative energy: biofuels advantages and disadvantages (2016)

25. Commonwealth Scientific and Industrial Research Organisation, Biofuels in Australia: an overview of issues and prospects (2007)

26. M. Puri, R. Abraham, C.J. Barrow, Biofuel production: prospects, challenges and feedstock in Australia, Renew. Sustain. Energy Rev. 16, 6022 (2012)

27. Yara, Yara Fertilizer Industry Handbook (Yara International, 2017). Available from: http://yara.com/doc/245619_Fer tilizer_Industry_Handbook_2017.pdf

28. Unite $\bar{d}$ Nations Framework Convention on Climate Change, Reducing emissions from deforestation and forest degradation in developing countries (2017)

29. Clean Energy Council, Australian Bioenergy Roadmap, Setting the direction for biomass in stationary energy to 2020 and beyond (2008)

30. D. Batten et al., Microalgae for Biofuel Production. Energy Transformed Flagship (CSIRO, 2016). Available from: http://www.aie.org.au/data/pdfs/proceedings/2012_pro ceedings/Presentation_DBatten.pdf

31. FAO, How to feed the world in 2050, Rome, Italy (2009)

32. N.A. Sasongko, R. Noguchi, T. Ahamed, T. Takaigawa, Introduction of integrated energy plantation model for microalgae-using Palm Oil Mill Effluent (POME), J. Jpn. Inst. Energy 94, 561 (2015)

33. U.S. Department of Energy (DOE), National Algal Biofuels Technology Review (Office of Energy Efficiency and Renewable Energy, Bioenergy Technologies Office, 2016)

Cite this article as: Nugroho Adi Sasongko, Charlotte Thorns, Irina Sankoff, Shu Teng Chew, Sangita Bista, Transitioning to sustainable use of biofuel in Australia, Renew. Energy Environ. Sustain. 2, 25 (2017) 